\title{
Data report: anisotropy of magnetic susceptibility of sand layers and detrital carbonate layers in deep-sea sediments from the Labrador Sea, North Atlantic ${ }^{1}$
}

\author{
Kiichiro Kawamura ${ }^{2}$ and Toshiya Kanamatsu ${ }^{3}$
}

\begin{abstract}
Chapter contents
Abstract.....................

Introduction $\ldots \ldots \ldots \ldots \ldots \ldots \ldots \ldots \ldots$

Core description $\ldots \ldots \ldots \ldots \ldots \ldots \ldots$

Methods ..................

Results .................... 2

Acknowledgments............... 3

References................. 3

Figures................... 5

Tables.................... 9
\end{abstract}

\begin{abstract}
'Kawamura, K., and Kanamatsu, T., 2011. Data report: anisotropy of magnetic susceptibility of sand layers and detrital carbonate layers in deepsea sediments from the Labrador Sea, North Atlantic. In Channell, J.E.T., Kanamatsu, T., Sato, T., Stein, R., Alvarez Zarikian, C.A., Malone, M.J., and the Expedition 303/306 Scientists, Proc. IODP, 303/306: College Station TX (Integrated Ocean Drilling Program Management International, Inc.). doi:10.2204/iodp.proc.303306.215.2011

2Fukada Geological Institute, 2-13-12

Honkomagome, Bunkyo, 113-0021 Tokyo, Japan. kichiro@fgi.or.jp

3Japan Agency for Marine Science and Technology, 2-15 Natsushima, Yokosuka, 246-0041 Kanagawa, Japan.
\end{abstract}

\begin{abstract}
Microfabrics of sand and detrital carbonate layers were deduced from a study on magnetic susceptibility anisotropy of drill core sediments obtained from Site U1305 during Integrated Ocean Drilling Program Expedition 303. The magnetic minerals that contribute to the magnetic susceptibility and their anisotropy are assumed to be ferrimagnetic minerals according to their magnetic hysteresis analyses. Maximum magnetic susceptibility (Kmax) directions of those layers are largely scattered, but Kmax resides in the southeast margin of the diagram with $5^{\circ}-10^{\circ}$ inclination. $\mathrm{Kmin}$ is mostly concentrated in a vertical direction with a $5^{\circ}-10^{\circ}$ northwest plunge.
\end{abstract}

\section{Introduction}

Knowledge of deepwater ocean currents is crucial to determining the transportation system of ocean floor sediments. Velocities of present-day deepwater currents are generally high enough to transport sediments (Stow and Holbrook, 1984), for instance, 20 $\mathrm{cm} / \mathrm{s}$ in the Hatton-Rockall Basin north of Ireland, $30 \mathrm{~cm} / \mathrm{s}$ in the Greenland-Iceland-Faeroes Ridge section north of Scotland, and $5-20 \mathrm{~cm} / \mathrm{s}$ on the continental slopes of North America.

Bottom current deposits as a drift in the North Atlantic lead to the formation of sites with high sedimentation rates. The Eirik Drift, located at the foot of the continental slope off the southern margin of Greenland (Chough and Hesse, 1984), is the largest of such thick sediment accumulation sites (Stow and Holbrook, 1984). This drift is an indicator of the North Atlantic paleocurrent system, especially that of the Western Boundary Undercurrent (WBU), at the millennium timescale.

The paleocurrent directions of ocean bottom sediments were analyzed using anisotropy of magnetic susceptibility (AMS) (e.g., Rees, 1965), both on the Norwegian Sea sediments (Kissel et al., 1998) and on the Nova Scotia continental rise (Shor et al., 1984). AMS can give us a paleocurrent history of sediments by preferred orientation of magnetic minerals parallel (or perpendicular) to the current direction (e.g., Rees, 1965), but those of the Eirik Drift have not been examined yet.

In this paper, we report the AMS of siliciclastic sand and detrital carbonate layers recovered in drill cores from Integrated Ocean Drilling Program (IODP) Site U1305. Site U1305 is located at the 
south margin of the Eirik Drift (Fig. F1). Furthermore, we examined constituent magnetic minerals contributing to AMS using rock magnetic methods.

\section{Core description}

The $313 \mathrm{~m}$ long core was obtained during IODP Expedition 303, on board the R/V JOIDES Resolution, from a water depth of $3459 \mathrm{~m}$ and located at the southernmost point of the Eirik Drift (Fig. F1).

The core is composed of mostly silty clay with siliciclastic grains and siliceous biogenic tests (see the "Site U1305" chapter [Expedition 303 Scientists, 2006b]). The silty clay is intercalated with siliciclastic sand and detrital carbonate layers. Most of the sand layers are relatively dark in color and have sharp basal contacts, parallel laminae (with local cross-laminae), and a fining-upward structure (Fig. F2A); these features show the sediments are probably of turbidite origin. The sand carries high magnetic susceptibility. The detrital carbonate layers are characterized by the intercalations of pale green bands with light gray detrital carbonate laminae (Fig. F2B). They have low magnetic susceptibility.

\section{Methods}

\section{Anisotropy of magnetic susceptibility and paleomagnetism}

The AMS analysis was conducted using a Kappabridge KLY 4 magnetic anisotropy susceptometer (AGICO Co. Ltd., Czech Rep.) in sediments with intercalated turbiditic sand and detrital carbonate layers.

AMS is demonstrated by the orientation of magnetic particles (Tarling and Hrouda, 1993). It can be represented by an ellipsoid defined by three principal axes: maximum (Kmax), intermediate (Kint), and minimum (Kmin) susceptibility. Hereafter, the AMS ellipsoid will be used throughout the paper. The AMS parameters magnetic lineation $(L)$, magnetic foliation $(F)$, anisotropy degree $(P)$, corrected anisotropy degree $\left(P^{\prime}\right)$, and shape parameters $T$ and $q$ calculated from the three principal axes are reported (Tarling and Hrouda, 1993).

We measured AMS and paleomagnetism using the working and archive halves, respectively. A total of 68 samples from the siliciclastic sand layers and 12 from the detrital carbonate layers were selected for AMS measurements. The northern magnetized direction in the samples, which deviated during core sampling, was determined by paleomagnetic declinations and was used to correct the AMS orientations. To do this we used a 2G-Enterprise superconducting magnetometer (2G-Enterprises, CA, USA) available on the JOIDES Resolution. Declination data were obtained successively by applying $10 \mathrm{mT}$ alternatingfield demagnetizations (see the "Expedition 303 summary" and "Expedition 306 summary" chapters [Expedition 303 Scientists, 2006a; Expedition 306 Scientists, 2006]). Because the declination data are rotated gradually downward because of a twist during coring within one core, magnetic north was calculated using the least-squares method (Fig. F3). Magnetic north of the archive half cores was adjusted for working halves by adding $180^{\circ}$. A correction to magnetic north is applied by the following equation:

Kmax declination $($ corrected $)=$ Kmax declination - declination of paleomagnetism.

\section{Magnetic hysteresis}

Because all minerals in marine sediments contribute to AMS to various degrees, it is important to define the kind of mineral most responsible for the measured magnetic fabric. This is done by following a magnetic hysteresis analysis using a MicroMag AGM2900 Model (Princeton Co. Ltd., UK). The MicroMag measures susceptibility in high magnetic fields $\left(K_{\mathrm{hf}}\right)$ of $500-900 \mathrm{G} . K_{\mathrm{hf}}$ is generally a result of mainly paramagnetic minerals rather than ferrimagnetic minerals (Housen and Sato, 1995; Housen, 1997). Low-field susceptibility $\left(K_{\mathrm{If}}\right)$ in sediments measured at $0.04 \mathrm{mT}$ using the KLY 4 can be subdivided into components that are contributed by both ferrimagnetic and paramagnetic minerals (Housen and Sato, 1995; Housen, 1997). The ratio of $K_{\mathrm{hf}} / K_{\mathrm{lf}}$ is inversely proportional to the relative contribution of ferrimagnetic minerals to $K_{\mathrm{lf}}$ (Housen and Sato, 1995; Housen, 1997).

\section{Results}

Most magnetic susceptibilities of the sand layers are $\sim 2.0 \times 10^{-6}$ to $4.0 \times 10^{-6} \mathrm{~m}^{3} / \mathrm{kg}$, and those of detrital carbonate layers are relatively low at $1.0 \times 10^{-7}$ to 3.0 $\times 10^{-7} \mathrm{~m}^{3} / \mathrm{kg}$ (Table T1). This result corresponds to the onboard measurement results as shown in the "Site U1305" chapter (Expedition 303 Scientists, 2006b). AMS parameters ( $L, F, P, P^{\prime}, T$, and $\left.q\right)$ are shown in Table T1.

The magnetic minerals that contribute to the magnetic susceptibility and their anisotropy are assumed to be ferrimagnetic minerals according to their $K_{\mathrm{hf}} / K_{\mathrm{lf}}$ ratio. This reflects the contribution percentage of paramagnetic minerals at low magnetic field, which is $<15 \%$ (Table T2), suggesting that the contribution is $>85 \%$ for ferrimagneric minerals. We note a signif- 
icant difference in $K_{\mathrm{hf}} / K_{\mathrm{lf}}$ ratios between detrital carbonate and sand layers samples.

Three stereographic projections (Fig. F4) show the orientations of Kmax, Kint, and Kmin, with rose diagrams of Kmax declination. Kmax directions are largely scattered, but the majority of Kmax values in sand layers resides in the northeast of the diagram (with $5^{\circ}-10^{\circ}$ inclination) with subordinate southplunging ones. Kmin values are mostly concentrated in a vertical direction with $5^{\circ}-10^{\circ}$ northwest plunge. Kmax directions in the detrital carbonate layers dominantly plunge to the south. On the basis of previous studies associated with paleocurrent analyses using the AMS (e.g., Taira, 1989), Kmax direction in this result may correspond to the paleocurrent direction, indicating that the directions in the sand layers and detrital carbonate layers are from south to north.

\section{Acknowledgments}

The samples analyzed in this study were provided by the Integrated Ocean Drilling Program (IODP). IODP is sponsored by the U.S. National Science Foundation (NSF) and participating countries under management of IODP Management International. Part of this study was funded by the Japan Agency for Marine Science and Technology. The authors gratefully acknowledge Dr. Tadashi Sato (Fukada Geological Institute) for kindly revising an early version of the manuscript. Professor Naoto Ishikawa helped to measure magnetic hysteresis in the samples. We greatly appreciate Dr. Lucia de Abreu (Cambridge University), Sasha N.B. Leigh (NERC), Dr. Ann de Vernal (University of Quebec), and Dr. Roy H. Wilkens, Nancy Niklis (University of Hawaii), and Dr. Michael Strasser, our reviewers, for providing useful suggestions and comments.

\section{References}

Chough, S.K., and Hesse, R., 1985. Contourites from Eirik Drift, south of Greenland. Sediment. Geol., 41(2-4):185199. doi:10.1016/0037-0738(84)90061-7

Expedition 303 Scientists, 2006a. Expedition 303 summary. In Channell, J.E.T., Kanamatsu, T., Sato, T., Stein, R., Alvarez Zarikian, C.A., Malone, M.J., and the Expedition 303/306 Scientists, Proc. IODP, 303/306: College Station, TX (Integrated Ocean Drilling Program Management International, Inc.). doi:10.2204/ iodp.proc.303306.101.2006
Expedition 303 Scientists, 2006b. Site U1305. In Channell, J.E.T., Kanamatsu, T., Sato, T., Stein, R., Alvarez Zarikian, C.A., Malone, M.J., and the Expedition 303/306 Scientists, Proc. IODP, 303: College Station, TX (Integrated Ocean Drilling Program Management International, Inc.). doi:10.2204/iodp.proc.303306.105.2006

Expedition 306 Scientists, 2006. Expedition 306 summary. In Channell, J.E.T., Kanamatsu, T., Sato, T., Stein, R., Alvarez Zarikian, C.A., Malone, M.J., and the Expedition 303/306 Scientists, Proc. IODP, 303/306: College Station, TX (Integrated Ocean Drilling Program Management International, Inc.). doi:10.2204/ iodp.proc.303306.109.2006

Hillaire-Marcel, C., and Bilodeau, G., 2000. Instabilities in the Labrador Sea water mass structure during the last climatic cycle. Can. J. Earth Sci., 37(5):795-809. doi:10.1139/cjes-37-5-795

Hillaire-Marcel, C., de Vernal, A., Bilodeau, G., and Wu, G., 1994. Isotope stratigraphy, sedimentation rates, deep circulation, and carbonate events in the Labrador Sea during the last $200 \mathrm{ka}$. Can. J. Earth Sci., 31(1):63-89. doi:10.1139/e94-007

Housen, B.A., 1997. Magnetic anisotropy of Barbados prism sediments. In Shipley, T.H., Ogawa, Y., Blum, P., and Bahr, J.M. (Eds.), Proc. ODP, Sci. Results, 156: College Station, TX (Ocean Drilling Program), 97-105. doi:10.2973/odp.proc.sr.156.010.1997

Housen, B.A., and Sato, T., 1995. Magnetic anisotropy fabrics from the Cascadia accretionary prism. In Carson, B., Westbrook, G.K., Musgrave, R.J., and Suess, E. (Eds.), Proc. ODP, Sci. Results, 146 (Pt. 1): College Station, TX (Ocean Drilling Program), 233-254. doi:10.2973/ odp.proc.sr.146-1.217.1995

Kissel, C., Laj, C., Mazaud, A., and Dokken, T., 1998. Magnetic anisotropy and environmental changes in two sedimentary cores from the Norwegian Sea and the North Atlantic. Earth Planet. Sci. Lett., 164(3-4):617626. doi:10.1016/S0040-1951(98)00223-6

Rees, A.I., 1965. The use of anisotropy of magnetic susceptibility in the estimation of sedimentary fabric. Sedimentology, 4(4):257-271. doi:10.1111/ j.1365-3091.1965.tb01550.x

Shor, A.N., Kent, D.V., and Flood, R.D., 1984. Contourite or turbidite?: magnetic fabric of fine-grained Quaternary sediments, Nova Scotia continental rise. In Stow, D.A.V., and Piper, D.J.W. (Eds.), Fine-Grained Sediments: Deep-Water Processes and Facies. Geol. Soc. Spec. Publ., 15:257-273. doi:10.1144/GSL.SP.1984.015.01.17

Stow, D.A.V., and Holbrook, J.A., 1984. North Atlantic contourites: an overview. In Stow, D.A.V., and Piper, D.J.W. (Eds.), Fine-Grained Sediments: Deep-Water Processes and Facies. Geol. Soc. Spec. Publ., 15:245-256. doi:10.1144/ GSL.SP.1984.015.01.16

Taira, A., 1989. Magnetic fabrics and depositional processes. In Taira, A., and Masuda, F. (Eds.), Sedimentary 
Facies in the Active Plate Margin. Adv. Earth Planet. Sci., 43-77.

Tarling, D.H., and Hrouda, F., 1993. The Magnetic Anisotropy of Rocks: London (Chapman and Hall).
Initial receipt: 15 March 2011

Acceptance: 16 June 2011

Publication: 30 September 2011

MS 303306-215 
Figure F1. Bathymetric map showing the location of Site U1305 and the nature of the present-day current system in the Northwest Atlantic (see the "Site U1305" chapter [Expedition 303 Scientists, 2006b]; HillaireMarcel and Bilodeau, 2000; Hillaire-Marcel et al., 1994); NAMOC = Northwest Atlantic Mid-Ocean Channel, WBUC = Western Boundary Undercurrent. The bathymetric map was compiled from ETOPO2 data using GMT ver. 3.0. Contours are $1000 \mathrm{~m}$ intervals.

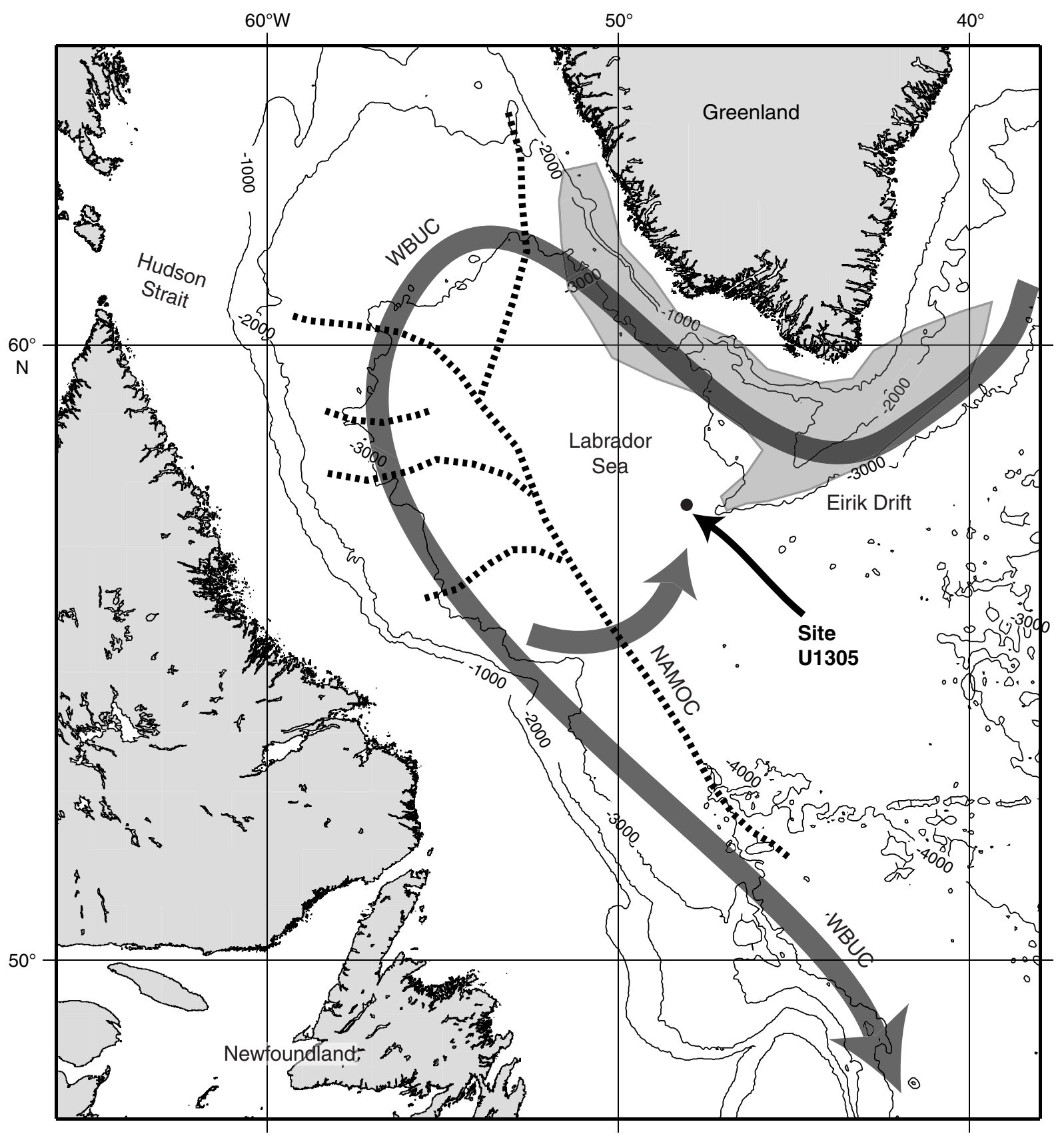


Figure F2. Magnetic susceptibilities of (A) a siliciclastic sand layer recovered from Section 303-U1305A-24H$5 \mathrm{~W}$ at 251.30-252.80 meters composite depth (mcd) and (B) a detrital carbonate (DC) layer recovered from Section 303-U1305A-25H-2W at 252.20-253.70 mcd. The siliciclastic sand layer is characterized by high magnetic susceptibility, relatively dark color, sharp basal contacts, and the development of laminae (A). Magnetic susceptibility from 252.70 to 252.80 mcd in A was very low, with probably error values. The DC layer is characterized by low magnetic susceptibility, relatively light color, and thin layers of DC grains (B). Photographs were taken using the Section Half Imaging Logger on the JOIDES Resolution. Magnetic susceptibility was measured using the Whole-Round Multisensor Logger on the JOIDES Resolution (see the "Site U1305" chapter [Expedition 303 Scientists, 2006b]).

A

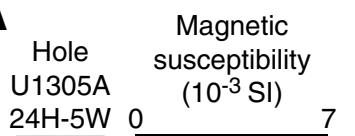

$24 \mathrm{H}-5 \mathrm{~W}$

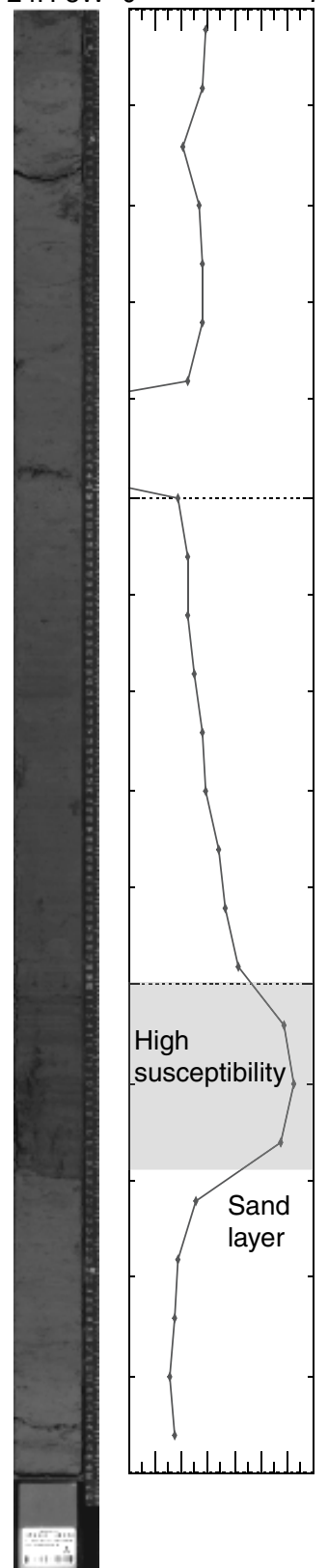

B
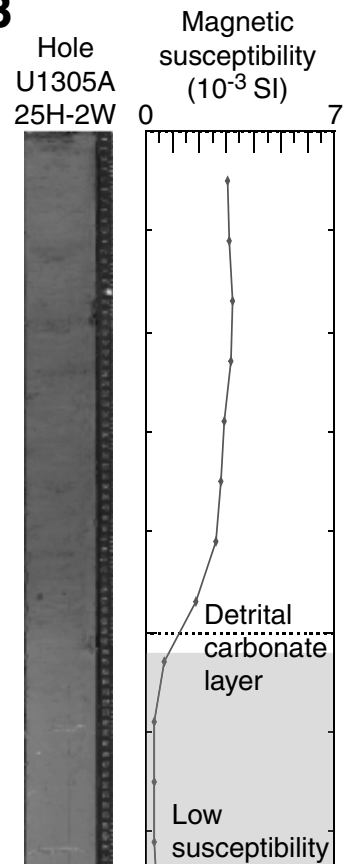
Figure F3. An example of reconstruction of paleomagnetic north in drilled cores. Open circles are declination data of paleomagnetism in archive halves of Sections 303-U1305A-20H-1A through $20 \mathrm{H}-6 \mathrm{~A}$ at 210.16-212.60 meters composite depth (mcd). A solid line shows a regression line of the declination calculated by the leastsquares method. Data are rotated gradually downward because of a twist during coring within one core. These declinations of paleomagnetism were generated by subtracting $180^{\circ}$ from the original declination of paleomagnetism calculated by the least-squares method for the north correction.

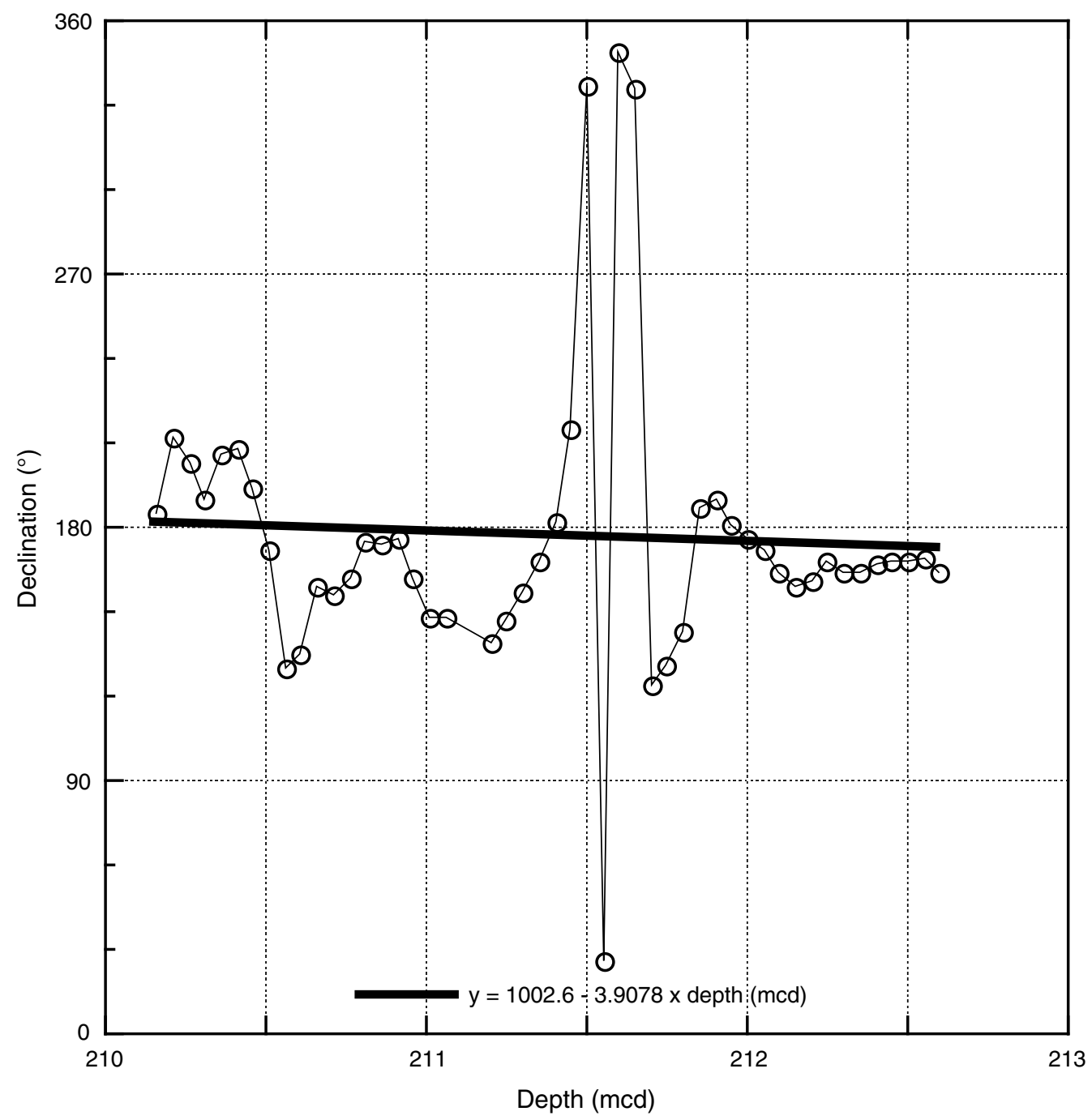


Figure F4. Graphic representations of anisotropy of magnetic susceptibility data, Site U1305. The stratigraphic column on the left shows the distributions of different lithological units. The three stereoplots (lower hemisphere) to the right show the directions of the principal axes of magnetic ellipsoids (Kmax $>$ Kint $>K \min )$ in each layer. Rose diagrams in the centers of the stereoplots represent the orientations of $K \max$ in $10^{\circ}$ each. mcd = meters composite depth.
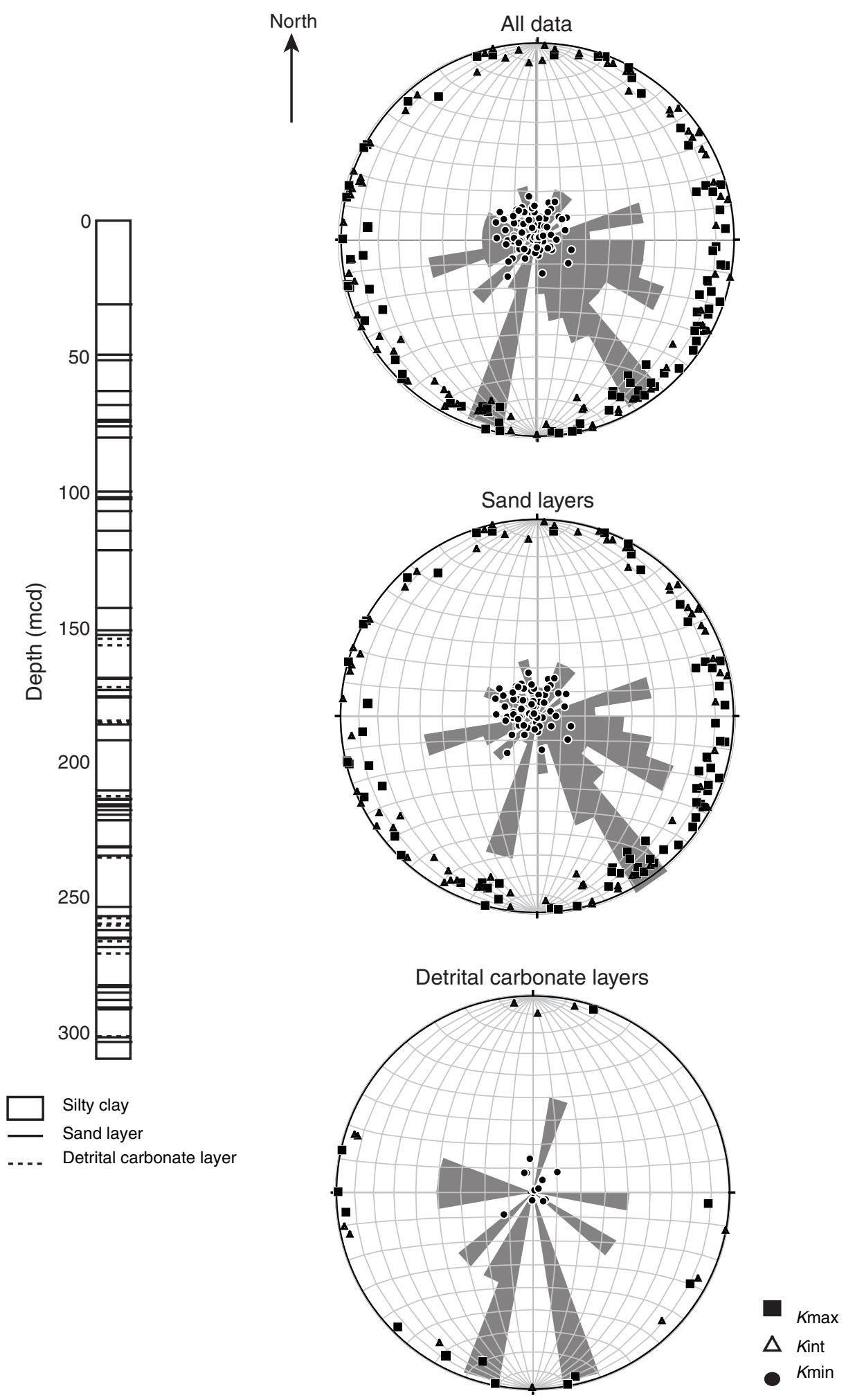
Table T1. Anisotropy of magnetic susceptibility data and approximate declination of paleomagnetism of siliciclastic sand layers and detrital carbonate layers in Site U1305 cores. This table is available in an oversized format. 
Table T2. Ratio of $K_{\mathrm{hf}}$ and $K_{\mathrm{lf}}$, Site U1305.

\begin{tabular}{lccccc}
\hline $\begin{array}{c}\text { Hole, core, section, } \\
\text { interval }(\mathrm{cm})\end{array}$ & $\begin{array}{c}\text { Depth } \\
(\mathrm{mcd})\end{array}$ & $\begin{array}{c}K_{\mathrm{lf}} \\
\left(\mathrm{m}^{3} / \mathrm{kg}\right)\end{array}$ & $\begin{array}{c}K_{\mathrm{hf}} \\
\left(\mathrm{m}^{3} / \mathrm{kg}\right)\end{array}$ & $K_{\mathrm{hf}} / K_{\mathrm{lf}}$ & Remarks \\
\hline 303- & & & & & \\
U1305A-20H-6W, 54-56 & 211.69 & $2.75 \mathrm{E}-07$ & $5.28 \mathrm{E}-08$ & 19.23 & $\mathrm{DC}$ \\
U1305A-25H-6W, 87-89 & 263.45 & $2.34 \mathrm{E}-07$ & $3.69 \mathrm{E}-08$ & 15.76 & DC \\
U1305A-22H-4W, 61-63 & 229.81 & $2.66 \mathrm{E}-06$ & $8.68 \mathrm{E}-08$ & 3.27 & $\mathrm{Sa}$ \\
U1305B-26H-4W, 62-64 & 266.09 & $3.48 \mathrm{E}-06$ & $1.34 \mathrm{E}-07$ & 3.85 & Sa \\
U1305B-28H-4W, 62-64 & 286.51 & $3.44 \mathrm{E}-06$ & $6.55 \mathrm{E}-08$ & 1.90 & Sa \\
\hline
\end{tabular}

$K_{\mathrm{hf}}=$ magnetic susceptibility under a high magnetic field of $600-900 \mathrm{G}, K_{\mathrm{lf}}=$ initial magnetic susceptibility by KLY 4 . DC = sample collected from a detrital carbonate layer, $\mathrm{Sa}=$ sample collected from a siliciclastic sand layer. 